\title{
The use of music and songs in developing the four skills
}

\author{
Abderrazak EL Kemma
}

Faculty of Letters and Human Sciences, Ibn Tofail University, Kenitra, Morocco

\begin{abstract}
No one doubts the importance of songs in motivating students to learn foreign languages. Research shows that songs are very effective teaching tools. Because of being both educating and entertaining authentic materials, songs inclusion as an essential part of the syllabus has become a must in the learning-teaching process. In this respect, this article is threefold. It aims at raising the teachers awareness to the effectiveness of songs as one of the most successful teaching components. It also suggests some tried and tested ways to present them. Most importantly, the paper highlights the interrelationship between teaching songs and developing the four skills: listening, speaking, reading and writing.
\end{abstract}

Keywords - songs, teaching tools, learning foreign languages, educating, entertaining, the four skills, authentic materials.

\section{INTRODUCTION}

Research shows that human beings learn a lot but retain a small quantity of which songs take their share. In other words, songs enter the mind and stick there; they become part of the human being. Nowadays, songs are everywhere and almost all adolescents have their favourite songs that they cannot help repeating while revising, going to school, having a shower, and so on. In fact, music and songs have become part of the young people's inner world that should be taken into consideration at the level of education. Murphey (1992, p. 7) argues that "it is very hard to escape music and song ... It would seem that the only place music and song is slow to catch on is in school!" Similarly, Hassim (2006, p. 3) asserts that "song teaching has not yet been given its due importance in FLT in Morocco, either through a total or partial negligence." Such negligence would impede reaching progress in learning English. Thus, it is high time high school teachers included songs in their lesson plans as they are proved to be effective teaching tools. Teachers have to spice up their lesson plans with songs as one of the best alternatives available in the teaching process.

No one can deny the positive contribution of songs and the activities that teachers may build around to enhance their students' English. Really, songs can be so motivating that they are not only entertaining but also educating in the sense that teachers can exploit them to improve the four skills in a relaxing and welcoming atmosphere. They do facilitate the task for teachers, especially while dealing with uninterested students, thereby rekindling interest and instilling into them a sense of love towards the target language.

By and large, this paper is an attempt to highlight the vital importance of using songs as a regular activity in teaching English in Moroccan high schools. Besides, it stresses some tried and trusted techniques in presenting songs which easily integrate with and then develop the four skills.

\section{REVIEW OF LITERATURE}

\subsection{SONGS' CONTRIBUTION}

It has become common knowledge in the literature that songs are advantageous in language learning. "Many of us have experienced with amazement how quick students are at learning songs" (Murphey, op. cit., p. 6) Simply, students are high achievers when it comes to songs. Teachers, therefore, can take advantage of their students' love towards music and songs and make them learn in a relaxed atmosphere. The more comfortable and less anxious the learners, the more rapidly they progress (Dulay, Burt and Krashen, 1982, p. 51).

Throughout the research literature, second language learning has been the question of differential success. It has been observed countless times that within the same language environment some learners progress rapidly while others struggle and achieve only limited success. In this respect, Krashen's (1982, p. 31) 'affective 
filter' provides some answer to the limited progress in learning foreign languages; the higher the filter is, the little input students will take in. That is why it is a must to guaranteelow anxiety, self-confidence and high motivation towards the target language so as to maximise learning. Consequently, using songs is one among the most effective methods that lower the affective filter. Their efficiency manifests itself in joining education and entertainment together, and hence the word 'edutainment'.

Having recourse to Suggestopedia, as a method of teaching introduced by Lozanov (1975), Richards and Rodgers (2001, p. 100) have stated that "a most conspicuous feature of Suggestopedia is the centrality of music and musical rhythm to learning." They have raised Lozanov's standpoint that successful learning takes place mostly in relaxing environments where psychological barriers to learning happen to be eliminated (ibid., p.101). "The student's relaxed mental state, brought about by classical music ... is believed to increase the receptivity of the student to the new material" (Dulay, Burt and Krashen,1982, p. 51). In other words, maximizing learning the target language necessitates relaxing both the mind and the body. It seems that daily life stress and pressure, that most learners suffer from, are reduced to the minimum possible, leaving a room for learning and enjoyment to mix naturally and peacefully. It is this state which creates students who sometimes sing songs flawlessly as if they were native speakers:

Songs are an important aspect of culture, representing the history, folklore, and current idiom of a country. Singing can build students' confidence by allowing them to enjoy a degree of fluency in English before they have achieved it in speaking.(Prentice-Hall Regents Publications) ${ }^{1}$

Really, songs, or music in general, could bring about mental calmness and physical comfort that students are in dire need of to develop confidence in using the target language naturally. Research has proved that there is a strong relation between music and learning. Davies (2000) asserts that music makes the two hemispheres work together and therefore enhances learning:

Optimal learning occurs when the two hemispheres of the brain work together. Any teaching strategy, such as music, that integrates the functions of both hemispheres uses the natural design of the brain to make learning easier, faster, and more fun. (p. 148)

\footnotetext{
${ }^{1}$ Retrieved from:

https://sites.google.com/site/eslresource/music
}

Davies (ibid., p. 149) argues that music and learning are strongly connected to the extent that the former "makes it easier to remember information". Murphey (1992) also states that "music is highly memorable. Songs and music 'stick' in the head" (p. 3).Actually, teaching songs in the classroom is magic especially to students who suffer from attention-deficit (hyperactivity) disorder ${ }^{2}$. In other words, there are some students who are too active and cannot pay attention in the classroom and therefore learn nothing (Davies, op. cit., p. 150). In this context, teaching songs proves its effectiveness in creating an edutaining atmosphere which enables students to learn the new language naturally and effortlessly:

Music in the classroom reduces stress, increases productivity, regulates energy, and creates a relaxed, supportive learning environment. Such an environment aids students in learning. (Davies, ibid.)

Thus, most scholars agree upon the use of songs as successful teaching tools. No one doubts that music and songs are part and parcel of every culture and therefore of every language. In this respect, "the teaching of any language, especially foreign languages, should include song teaching as part of its normal and pedagogical practices" (Hassim, 2006, p. 3). Research proves that songs create a relaxing atmosphere which motivates learners and then encourages them to progress rapidly:

Music is a powerful stimulus for student engagement precisely because it speaks directly to our emotions while still allowing us to use our brains to analyse it and its effects if we so wish. A piece of music can change the atmosphere in a classroom or prepare students for a new activity. It can amuse and entertain, and it can make a satisfactory connection between the world of leisure and the world of learning in the classroom. (Harmer, 2007b, p. 319)

Lavery (2001, p. 85) has also pointed out that "students who are usually quiet become talkative. It disguises work for the work-shy class and is a great motivator". Likewise, Hassim (2006, p. 4) argues that "learners have a natural psychological predisposition to learn from and through songs; hence motivation is guaranteed." In fact, almost all learners, especially adolescents, love not only listening to but singing songs as well. Besides, nobody doubts the fact that through songs teachers teach both language and

\footnotetext{
${ }^{2}$ A medical condition, especially in children, that makes it difficult for them to pay attention to what they are doing, to stay still for long and to learn things (Oxford Advanced Learner's Dictionary, 2010, p. 81)
} 
culture. Songs do incorporate cultural values of a particular community. Put differently, songs are so rich that they can tell a lot about a certain group of people's culture in general. They form also a source of invaluable exposure to authentic language. Needless to say that songs form a kind of bridge connecting the students' inner world to what is happening in everyday life.

As shown above, Music and songs have the possibility of both relaxing the classroom atmosphere and involving the right hemisphere of the brain in the process of learning, and therefore making the experience holistic.

\subsection{PRESENTING SONGS}

Many are the ways suggested in the literature about how to effectively present songs in classrooms. However, opting for the common three-stage framework used for different kinds of listening provides a good opportunity to exploit songs to the full. Of course, songs may also work as an icebreaker putting students in a good mood and preparing them for the main lesson.

As far as the pre-listening stage is concerned, a variety of tried and tested activities may work. At this stage, Bilsborough $(2002)^{3}$ has suggested exploiting the song's title by writing it in the center of the board then asking students to predict the words or phrases they expect will hear. This phase is also characterized by pre-teaching some vocabulary items that are keywords in the song, or by having students discuss the song topic or brainstorm words they may hear that are related to the title. According to Lorenzutti (2014), this stage is so fruitful in that it helps "students engage in activities that activate schema or background knowledge of a song's main theme" (pp. 1415).

The while-listening stage is the main dish of song teaching. This phase is well-known for one classic activity, i.e. gap fill. Lorenzutti (2014) is a critic of this narrowing of the activities related to song teaching; "when it comes to designing a listening activity for a song, teachers tend to rely on the Gap Fill as the sole activity (p. 14)." Instead, teachers may resort to Murphy's (1992) resource book about song activities or they may devise their own ones for the sake of variety. They could divide the lyrics' sentences into two clauses or parts, putting each one on a separate coloured card and then ask students to reorder them correctly (Lorenzutti, op. cit., p. 18). Changing the lyrics' text may also be an interesting activity:

${ }^{3}$ http://www.teachingenglish.org.uk/article/listeningactivities-songs
Grammar can be emphasized by changing parts of speech (e.g., from "I have seen" to the incorrect "I have saw") or by eliminating articles, prepositions, etc. Likewise, both coherence and pronunciation awareness can be facilitated by changing content words (e.g., day/way). (Lorenzutti, ibid.)

Bilsborough (2002), also, suggests arbitrarily dictating some words that are part of the lyrics. The task here is that the teacher has to add one word which is not mentioned in the lyrics. Students listen to the song and tick off any word that is part of the lyrics until they are left with one word.The teacher may play the song again and then devise any activity they want to build around the song. They might work on developing their students' confidence through songs' gist listening, i.e. students pay attention to the main ideas, ignoring the details (Harmer, 2007a, p. 135; Lorenzutti, 2014, p. 16). In short, while-listening-stage activities are countless and this article raises a variety of tried and tested ones.

At the post-listening phase, teachers may also end up their song teaching invaluable activities. According to Lavery (2001, p. 87), songs can be a very good teaching tool to focus on identity at this stage. In such a phase, learners listen and say which age group or sex the singer is talking about; is the singer addressing the young, the old, women, men, etc.? Such questions are normally supplemented by justification. Word reference is also another type of questions that the teacher may exploit largely; 'what do 'I', 'she', and 'we' refer to in the song?' is a case in point.

No one doubts that songs are very flexible teaching components. They can be exploited in several ways. For instance, songs can be used in opening the class or what is often referred to in the literature as 'topic introduction', and therefore serve both a kind of relaxing and a smooth transitional warm up. Linse (2006, p. 38) says that "songs and poems are an excellent way to begin or end a lesson".

It is worth noting that, while presenting songs, teachers must pay attention to some mistakes that would impede reaching the objectives targeted. On the one hand, there are some don'ts that teachers should be fully aware of in the presentation of songs. Firstly, teachers should not permit too much noise at the back of the classroom in order to guarantee a clear voice. Secondly, teachers should not turn up the volume. Thirdly, it is not wise to use songs that include a lot of slang words. Above all, Lavery (ibid., p. 85) states that it is "a mistake to relegate songs to the Friday afternoon or end of term treat slot". On the other 
hand, the song presented should be well chosen. "The ideal song is short, slow, and clear; repeats key phrases; attracts students' attention; and teaches some natural, interesting language without offending anyone" (Payne, 2006, p. 42). Consequently, it is true that songs are so crucial that they should be incorporated in the teacher's lesson planbut making mistakes such as the above ones while presenting them would certainly hinder students' likelihood of learning from them.

On the whole, presenting songs in the right way surely provides a good opportunity for the teacher to build around them successful activities. Yet, having little knowledge about how to exploit them will be doomed to failure. To note, there should be a purpose for the teaching of songs; listening to songs for the sake of listening is pointless.

\subsection{SONGS AND THE FOUR SKILLS}

Literature shows that "no skill exists in isolation"; all of them are fully integrated in almost all learning activities (Harmer, 2007b, p. 310) "though one, in particular, is often the main focus of the sequence" (Harmer, 2001, p. 232). Therefore, high school teachers can make use of songs as vital teaching tools to develop their students' abilities in listening, speaking, reading and writing in a relaxing and welcoming classroom environment.

\subsubsection{LISTENING}

Songs have always been referred to as a pure listening activity. Therefore, nobody could imagine teaching listening in EFL classes without songs.

Several are the techniques that might be exploited in listening. Yet, most teachers exhaustively use the fill-inthe-blanks technique which has been given different names, including 'filling blanks', 'fill-ins', 'gaps fill' and 'the cloze'. Likewise, Murphey (1992, pp. 69-70) strongly recommends using this most popular technique in one of the following ways, depending on the level of the students:

1. Focus on a particularword class (verbs, prepositions, adjectives, etc.).

2. Include a glossary of the missing words.

3. Leave the same number of dashes as there are letters in the missing words, and make it easier for lower-level classes by putting in the first letter.

Harmer (2001) raises the effectiveness of listening for general understanding and for either specific or detailed information. To begin with, gist listening or listening for general understanding "without worrying too much about the details" is an excellent skill that should be instilled into students (p. 202). Subsequently, teachers have to make use of the listening-for-specific-information skill. To note, this skill's aim is to train students, as Scrivener (2005, p. 171) has mentioned, to "catch specific details such as names numbers, addresses, etc." Harmer (2001, op. cit.) argues that this skill is so beneficial; "we listen to the news, only concentrating when the particular item that interests us comes up." Finally, listening for detailed information is also another skill that people use to understand everything they listen to. "If we are in an airport and an announcement starts with Here is an announcement for passengers on flight AA671 to Lima (and if that is where we are going), we listen in a concentrated way to everything that is said" (Harmer, ibid.).

Consequently, although the techniques that can be used to exploit songs and sharpen the listening skill are great in number, it seems that the cloze is the most popular activity over-used by teachers all over the world.

\subsubsection{SPEAKING}

Unlike a lot of people who think that song teaching is solely exploited via listening, a variety of speaking activities can be built around songs. In fact, using songs in EFL classes is a good chance for students to express themselves freely as lyrics, in general, are open to interpretations.

Targeting the speaking skill, while teaching songs, would certainly be of great benefit to students. Research shows that building the skill of speaking around song teaching provides a golden opportunity to discuss the lyrics as freely as possible. Therefore, both the singer's feelings and the theme of the song can be positively exploited. The teacher may establish a kind of group discussion, for example, on the psychological state of the singer whether they are happy, sad, disgusted, anxious, lonely, embarrassed or angry (Lavery, 2001). This leads to discuss the theme of the song in general. To note, the theme should be well chosen in that it can relate reality to the students' inner worlds. Moving from the general atmosphere of the song to that of the classroom, the teacher may ask students about their standpoints of the topic, raising the situation about what students would do if they were put in the same situation. Lavery (ibid.) has further pointed out that teachers may use 'role play' activities after listening to the song. What the teacher has to do here is to ask two students, for instance, to play the roles of the song's characters in front of the class. According to Lavery (ibid., p. 36), teachers may also ask their students to prepare an oral project at home. Students may choose a singer or a band and prepare a biography for them, including their 
favorite songs, the musical instruments they play with, and so on so forth. Coming to the classroom, students have to deliver oral presentations about what they have chosen themselves to talk about.

By and large, if teachers could choose a good song whose theme makes a compromise between the syllabus and the students' inner world, students would feel it a pleasure to discuss it as it simply touches their reality. Songs, in general, are open to different interpretations which may serve as a solid basis for long discussions in the follow-up activity.

\subsubsection{READING}

Reading is an essential skill that learners should develop. Teachers could make use of songs exactly the same way they do with other reading texts, and thushelp their students learnabout reading sub-skills such as scanning and skimming.

It has been mentioned countless times in the literature that using songs in the classroom can be exploited in many a way, one of which is through the reading skill. Murphey $(1992$, p. 7) argues that because songs "are affective makes them many times more motivating than other texts." Similarly, Harmer (2001) points out that "one of the most useful kinds of text for students to work with is song lyrics, especially where the song in question is one which the students are very keen on" (p. 243). While reading the song, students should pay attention to every minute detail so as to be able to answer comprehension questions or any other activity related to the reading skill. Teachers may make use of "the song title, keywords, pictures and photos in the same way as when preparing reading texts" (Lavery, 2001, p. 85). According to Lo and Chai Fai Li (1998), the idea of matching the song's beginnings and ends also proves to be an effective way of showing the extent to which students have grasped the song lyrics.

To conclude, songs could really help in developing the student's reading skill. Learning takes place easily as the songs' teaching atmosphere is relaxing.

\subsubsection{WRITING}

Writing is generally agreed upon to be the most difficult skill. This productive skill is so demanding that it needs a lot of teachers' guidance and learners' practice.

It is common knowledge that songs can also be exploited in the writing skill. According to Lavery (op. cit., p. 88), songs can be used "as stimulus for writing." She has pointed out that the teacher may ask their students, after the listening phase, to do the following writing tasks:
1. Write the conversation between the singer and her friend as a telephone conversation.

2. Write a letter based on the song or send an email with the same subject heading as the song.

3. Write about the issues raised in the song. Write a letter to the editor of a national newspaper, drawing attention to these problems for young people/old people/families/communities/ immigrants/schools.

Murphey (1992) is also positive about the usefulness of music and songs in providing students with the inspiration to write in EFL classes. It seems that this musical atmosphere is able "to give energy where there is none, and to spark off images when students complain of having nothing to write about" (p. 37). So, having students listened and understood the song, Lo and Chai Fai Li (1998, p. 11) say that it is time for engaging students in creative composition, namely letter, story or conversation writings. To explain, Lo and Chai Fai Li (ibid.) have mentioned the 'Lemon Tree' song as an example which tackles a kind of conversation between father and son exactly as the case of Cat Steven's 'Father and Son'. Lo and Chai Fai Li (ibid.) have suggested that teachers may ask their students to get involved in a pair work in an imaginary task - one student imagines that $\mathrm{s} / \mathrm{he}$ is the father and the other, the son, and thus write a conversation of what happens exactly in the song. Moreover, Lavery (2001, p. 87) has proposed another writing activity to build around songs. She asks teachers to give "a song with distinct rhymes" in the form of a usual text that lacks punctuation marks. Lavery here stresses the fact that teachers should not tell students that it is a song. All students have to do is to punctuate the passage and find the rhymes. After that, the teacher has to play the song that will undoubtedly be a surprise. Now, the teacher invites them to check correction and compose the lyrics. In brief, so many are the writing activities that may be built around songs.

As stated above, unlike the false belief that songs can be exploited as a listening activity only, teachers can use them to teach speaking, reading and writing. In fact, songs are effective tools that suit all the four skills in a perfect way. As far as the activities are concerned, there are a lot of tried and tested ones that can be built around. What is advantageous for songs is that they are taught in an edutaining atmosphere which is not the case with other alternatives. 
Nowadays, motivating students to learn English has become a daunting task. In this respect, teachers can motivate them through the use of songs.In fact, songs may endear teachers to their students as the former have managed to reach their students' inner worlds. By doing so, teachers would find it easier to educate students in a relaxing atmosphere. In general, students take in anything they enjoyit. In view of this, teachers could seize the opportunity to present songs and then exploit the four skills in a smooth way.

\section{RESEARCH METHODOLOGY}

To come up with both reliable and convincing results, the study used the technique of questionnaire to collect data. In this respect, a questionnaire was addressed to high school teachers belonging to El Farabi and Sidi Aissa high schools in Had Kourt and Souk Arbaa El Gharb respectively. The questionnaire was made of 10 questions. The informants were asked to choose the right option(s) according to their exploitation of songs in their classes.
Document analysis was another method used to collect data. Accordingly, 6 textbooks were reviewed'Visa to the World' and 'Window on the World' recommended for Common Core, 'Ticket to English' and 'Gateway to English' for first year baccalaureate and 'Gateway 2 to English' and 'Insights into English' for second year baccalaureate.

The study's results were stated in tables and figures with parallel frequencies and percentages, and then analysed with reference to the literature.

\section{RESULTS AND DISCUSSION}

No one can deny the important role songs play in facilitating the task for teachers to educate and entertain students at the same time. Unfortunately, Moroccan textbooks do neglect them (Hassim, 2007). Conducting fieldwork, 6Moroccan textbooks were reviewed. The results show that Moroccan textbooks really neglect songs for $100 \%$ (table 1 )

Table 1. songs inclusion in the textbook

\begin{tabular}{|l|c|c|c|c|}
\hline & Frequency & Percent & Valid Percent & $\begin{array}{c}\text { Cumulative } \\
\text { Percent }\end{array}$ \\
\hline Valid No & 15 & 100,0 & 100,0 & 100,0 \\
\hline
\end{tabular}

When asked about their intervention, 11 respondents, representing $73.30 \%$, said that they do not use songs.Of course, this situation may result in increasing anxiety in EFL classes.By contrast, only 4 respondents, making $26.66 \%$, do select some interesting songs.
To understand the teachers' motives for their total or partial negligence of song teaching, four types of reasons were then provided as table 2 below shows.

Table 2. factors behind total or partial negligence of song teaching in high schools

\begin{tabular}{|c|c|c|c|c|}
\hline & $\begin{array}{c}\text { Frequenc } \\
\mathrm{y}\end{array}$ & Percent & $\begin{array}{c}\text { Valid } \\
\text { Percent }\end{array}$ & $\begin{array}{c}\text { Cumulative } \\
\text { Percent }\end{array}$ \\
\hline $\begin{array}{l}\text { Valid the songs' absence in the textbook } \\
\text { thelength of syllabus } \\
\text { the noise songs cause to neighbouring classes } \\
\text { the physical constraints (the lack of electronic } \\
\text { equipment, etc) } \\
\text { Total }\end{array}$ & $\begin{array}{l}1 \\
10 \\
1 \\
3 \\
15\end{array}$ & $\begin{array}{r}6,7 \\
66,7 \\
6,7 \\
20,0 \\
100,0\end{array}$ & $\begin{array}{l}6,7 \\
66,7 \\
6,7 \\
20,0 \\
100,0\end{array}$ & $\begin{array}{c}6,7 \\
73,3 \\
80,0 \\
100,0\end{array}$ \\
\hline
\end{tabular}

Ten respondents, making $66.7 \%$, argued that the length of the syllabus is the reason behind not teaching songs. Three other respondents, representing $20 \%$, attributed their partial negligence to the factor of the classroom physical constraints. Still, two participants said that both the absence of songs in the textbook and the noise that song 
teaching may cause to neighbouring classes are the motives justifying their partial negligence. It sounds, therefore, that most participants are concerned about covering the syllabus, which is too long. The lack of electronic equipment, such as CD players and hi-fis, is also another explanation influencing the teaching of songs in the high school. Of course, disturbing other classes while teaching songs is not a good reason. The teaching of English is different from other school subjects.Teachers of English could fix this problem at the very beginning of the year; they might teach in classrooms that are in the corners of the school so as to minimise noise.

On the other hand, the participants' motives for not teaching songs was motivated, mainly, by the informal language these teaching tools often include (table 3 ).

Table 3. Teachers' motives for not using songs in their classes

\begin{tabular}{|c|c|c|c|c|c|}
\hline & & $\begin{array}{c}\text { Frequenc } \\
\mathrm{y}\end{array}$ & Percent & $\begin{array}{c}\text { Valid } \\
\text { Percent }\end{array}$ & $\begin{array}{l}\text { Cumulative } \\
\text { Percent }\end{array}$ \\
\hline \multirow[t]{3}{*}{ Valid } & $\begin{array}{l}\text { they incorporate many slang words and bad } \\
\text { grammar. }\end{array}$ & 2 & 13,3 & 18,2 & 18,2 \\
\hline & They introduce informal language. & 9 & 60,0 & 81,8 & 100,0 \\
\hline & Total & 11 & 73,3 & 100,0 & \\
\hline Missing & System & 4 & 26,7 & & \\
\hline Total & & 15 & 100,0 & & \\
\hline
\end{tabular}

The results above reveal that most teachers who do not teach songs expressed their own concerns about the inclusion of informal language in songs. These teachers might think that their job is to fight against inculcating these ready-made structures that students learn by heart while listening to songs. Yet, informal language is believed to be a plus as learners are in dire need of while interacting with native speakers, a fact that supports what is referred to in the literature as authentic language. Teachers are also concerned about the incorporation of slang words and bad grammar in songs though a careful selection of songs could save the situation.

Concerning the four participants who teach songs, their responses were different.

Table 4. Reasons for using songs in the classroom

\begin{tabular}{|ll|c|c|}
\hline & & Count & Column N \% \\
\hline they are educating & yes & 1 & $25,0 \%$ \\
& No & 3 & $75,0 \%$ \\
they are entertaining & yes & 1 & $25,0 \%$ \\
& No & 3 & $75,0 \%$ \\
they break the routine & yes & 4 & $100,0 \%$ \\
& No & 0 &, $0 \%$ \\
students like them & yes & 4 & $100,0 \%$
\end{tabular}

\begin{tabular}{|ll|c|c|}
\hline & & Count & Column N \% \\
\hline they are educating & yes & 1 & $25,0 \%$ \\
& No & 3 & $75,0 \%$ \\
they are entertaining & yes & 1 & $25,0 \%$ \\
& No & 3 & $75,0 \%$ \\
they break the routine & yes & 4 & $100,0 \%$ \\
& No & 0 &, $0 \%$ \\
students like them & yes & 4 & $100,0 \%$ \\
& No & 0 &, $0 \%$ \\
\hline
\end{tabular}

As table 4 above shows, while one participant uses songs because (1) they are educating, (2) they break the routine and (3) students like them, the second does so because (1) they are entertaining, (2) they break the routine and (3) students like them.It seems that both participants misunderstand the essential part of teaching songs in EFL classes. While the first does not target the entertaining part of songs, the second misses the educating one. Therefore, both participants would never reap good results. Having only $26.66 \%$ of the participating teachers who use songs in El Farabi and Sidi Aissa high schools is problematic. To make matter worse, the four participants use them inappropriately. 
As raised in the literature, songs teaching targets the four skills. However, the four respondents who teach songs in their classes prove to be in the dark regarding this issue.

Table 5. Skills targeted through song teaching

\begin{tabular}{|ll|c|c|}
\hline & & Count & Column N \% \\
\hline Listening & yes & 2 & $50,0 \%$ \\
& no & 2 & $50,0 \%$ \\
Reading & yes & 0 &, $0 \%$ \\
& no & 4 & $100,0 \%$ \\
Speaking & yes & 2 & $50,0 \%$ \\
& no & 2 & $50,0 \%$ \\
Writing & yes & 0 &, $0 \%$ \\
& no & 4 & $100,0 \%$ \\
\hline
\end{tabular}

The results show, in table 5 above, that two participants think that songs target two skills only: listening and speaking. Accordingly, such teachers would never think of integrating the four skills while teaching songs.

When it comes to the activities that teachers could build around songs, both participants ticked one out of ten activities. 'Filling the blanks' is the only activity the study's respondents usually resort to as figure 1 below demonstrates.

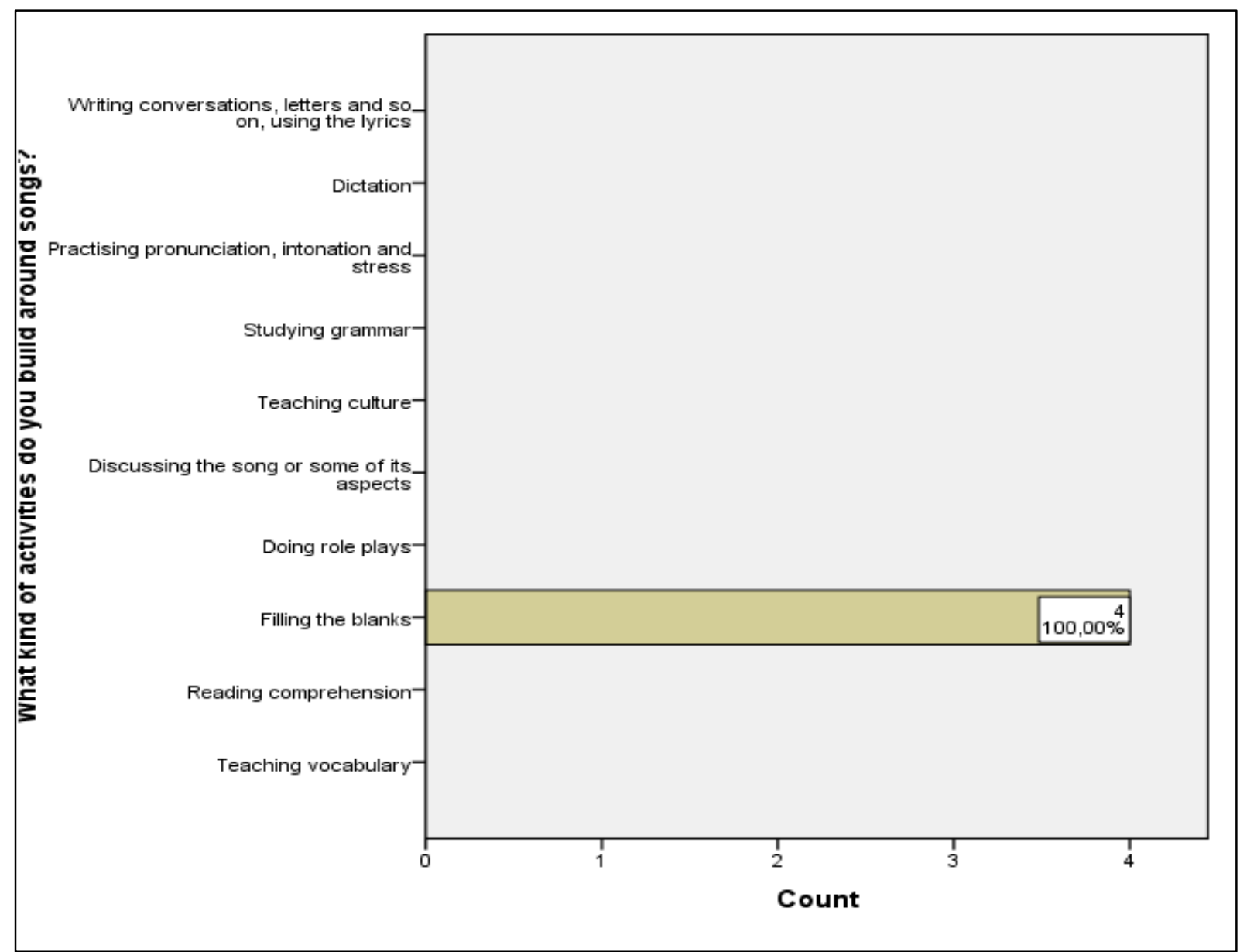

Fig.1: The activities built around songs teaching 
Put differently, teaching songs, these 4 teachers think of the 'gaps fill' activity and neglect tens of excellent activities, including 'teaching vocabulary', 'reading comprehension', 'doing role plays', 'discussing the songs or some of its aspects', 'teaching culture', 'studying grammar', 'practising pronunciation, intonation and stress', 'dictation' and 'writing conversations, letters, and so on, using lyrics.' Nevertheless, teachers can exploit songs through the teaching of the four skills.

Exploiting songs, these four participants tended to teach songs in a direct way as figure 2 below indicates.

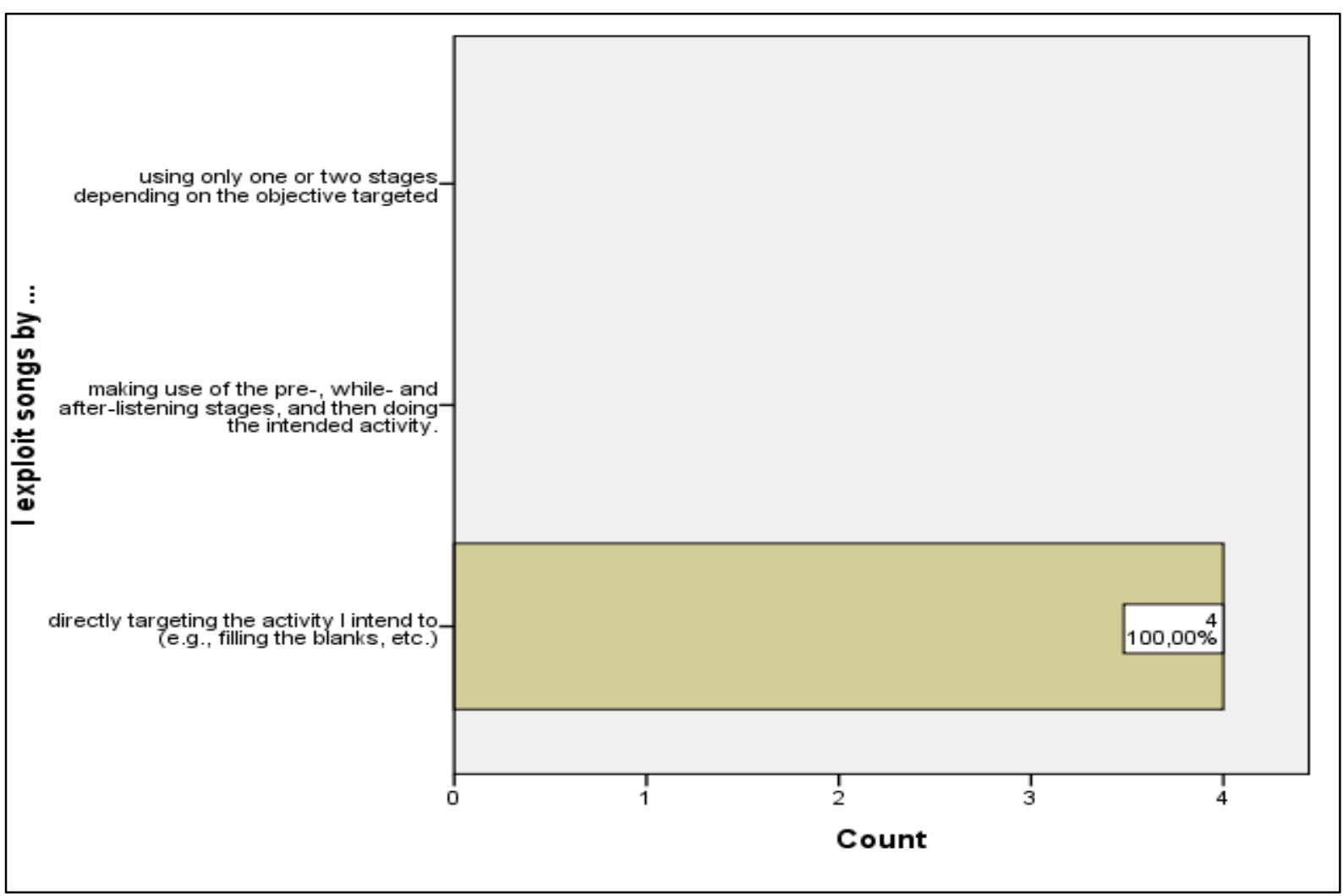

Fig.2: Songs' exploitation way

The figure's results show that $100 \%$ of the participants who teach songs directly target their activities without making use of the listening stages that are of great help to students in terms of the skills to be exploited at each stage.
Such a way of using songs is ineffective; it cannot help in improving the learners' level at all.

According to these same teachers, learners usually get excited when it is time for song activities.

Table 6. learners' feelings about songs

\begin{tabular}{|ll|c|c|c|c|}
\hline & & Frequency & Percent & Valid Percent & Cumulative Percent \\
\hline Valid & excited & 4 & 26,7 & 100,0 & 100,0 \\
Missing & System & 11 & 73,3 & & \\
Total & & 15 & 100,0 & & \\
\hline
\end{tabular}

Believing that students get excited when they listen to songs, high school teachers could do a lot to maximize motivation and check the progress of any language aspect taught before. They would, therefore, choose the right time for presenting songs. 
Table 7. Songs' Teaching time

\begin{tabular}{|c|c|c|c|}
\hline & & Count & Column N \% \\
\hline \multirow[t]{2}{*}{ at the beginning of the class as a warm-up } & yes & 0 &, $0 \%$ \\
\hline & no & 4 & $100,0 \%$ \\
\hline \multirow{2}{*}{$\begin{array}{l}\text { in the middle of the class so as to break the routine of the } \\
\text { activities }\end{array}$} & yes & 0 &, $0 \%$ \\
\hline & no & 4 & $100,0 \%$ \\
\hline \multirow[t]{2}{*}{ at the end of the class in order tohelp learners relax } & yes & 3 & $75,0 \%$ \\
\hline & no & 1 & $25,0 \%$ \\
\hline
\end{tabular}

The results above show that $75 \%$ of the participants usually use songs at the end of the class in order to help learners relax. There were other options to choose from, but nobody ticked them. Of course, relegating songs to a specific time is a mistake (Lavery, 2001). However, they can be of great help in case the teacher decides to revise or reinforce any language structure. In fact, one cannot talk at all about the effectiveness of songs in EFL classes without raising high school teachers' awareness about the way songs should be presented in classes, otherwise they would be considered as fillers to break the routine. As raised in literature, using songs to help learners relax is a good way to lower their filter, but it is not the only way possible. Given the 'other' option, one participant, representing $25 \%$, proved to relegate a whole session to songs. It sounds rewarding for such a teacher to take their time and present songs in one class, thereby exploiting the pre-, while and post-listening activities.

Finally, songs are a very essential part in today's adolescents' daily activities. Teachers must understand their students' world and use educating and entertaining songs. Nearly all students listen to songs at home, on the way to school and even while going to bed. Conducting research in the high school shows that most teachers either downgrade their efficacy or have little knowledge about their importance in foreign language teaching. Songs have been proved to be good alternatives for breaking the routine, learning with fun, spicing up the lesson plan, improving the students' skills, and so on. Using songs at least once a week, teachers would have a healthy atmosphere in which students are well-motivated to learn. In short, teachers should always think of songs as very good teaching tools.

\section{PEDAGOGICAL IMPLICATIONS}

Several are the pedagogical implications that should be taken into consideration if we want to improve the level of English in Moroccan high schools. It is high time textbook designers included songs as a staple activity at the end of each unit in the student's book. Concerning the lack of equipment, the Ministry of Education ought to assume its responsibility and provide high schools with the latest technological equipment.

It is common knowledge that adolescents listen to songs in English on a daily basis. The new technology allows them to listen to songs wherever they are. Teachers should therefore make wise use of songs and target the four skills in a variety of ways. Doing otherwise is not encouraging at all and can never result in progress in learning English. What is more, teachers have to try out exploiting songs, focusing on the pre-, while and afterlistening stages.

\section{CONCLUSION}

Nowadays, motivating students to learn English has become a daunting task. Yet, teachers must motivate them by hook or by crook. One way of doing this is to try to get nearer and nearer to them. In this respect, songs can make the distance between teachers and students short. They may, thus, endear teachers to their students as the former have managed to reach their students' inner worlds. By doing so, teachers would find it easier to educate students in a relaxing atmosphere. Really, songs can do a lot to improve the learning process, targeting mainly the four skills.

\section{REFERENCES}

[1] Bilsborough, K. (2002, July). Listening activities for songs. Retrieved

from 
http://www.teachingenglish.org.uk/article/listeningactivities-songs

[2] Davies, M. A. (2000). Learning ... the beat goes on. Childhood Education, 76(3), pp. 148-153.

[3] Dulay, H., Burt, M., \& Krashen, S. (1982). Lnguage two. New York: Oxford University Press.

[4] Harmer, J. (2001). The practice of English language teaching. Essex, England: Longman.

[5] Harmer, J. (2007a). How to teach English. Essex, England: Longman.

[6] Harmer, J. (2007b). The practice of English language teaching (2 ed.). Essex, England: Longman.

[7] Hassim, M. (2006). Video songs in the language classroom. Newsletter of the Moroccan Association of Teachers of English, 26(3-4), 1-16.

[8] Hornby, A. S. (2006). Oxford advanced learner's dictionary (7 ed.). USA: Oxford University Press.

[9] Krashen, S. D. (1982). Principles and practice in second language acquisition. Oxford: Pergamon.

[10] Lavery, C. (2001). Language assistant. England: British Council ELT. doi:0863554873

[11] Linse, C. (2006). Using songs and poems with young learners. English Teaching Forum, 44(2), pp. 38-45.

[12] Lo, R., \& Chi Fai Li, H. (1998). Songs enhance learner involvement. English Teaching Forum, 36(3), pp. 8-11.

[13] Lorenzutti, N. (2014). Beyond the gap fill: Dynamic activities for song in the EFL classroom. English Teaching Forum(1), pp. 14-21.

[14] Murphey, T. (1992). Music and song. Oxford: Oxford University Press.

[15] Payne, S. (2006). A song-based grammar lesson in record time. Teachers of English to Speakers of Other Languages, 3(1), pp. 42-45.

[16] Richards, J. C., \& Rodgers, T. S. (2001). Approaches and methods in language teaching. Cambridge: Cambridge University Press.

[17] Scrivener, J. (2005). Learning teaching: A guidebook for English language teachers (2 ed.). Oxford: Macmillan.

[18] Songs are among the best ways of teaching a foreign language. (n.d). Retrieved from https://sites.google.com/site/eslresource/music

[19] www.teachinggenglish.org.uk

[20] www.mate.org.ma

[21] https://sites.google.com/site/eslresource/music 